\title{
Antitumor activity of 7RH, a discoidin domain receptor 1 inhibitor, alone or in combination with dasatinib exhibits antitumor effects in nasopharyngeal carcinoma cells
}

\author{
QIU-PING LU ${ }^{1}$, WEN-DAN CHEN ${ }^{2}$, JIE-REN PENG ${ }^{1}$, YAO-DONG XU ${ }^{1}$, QIAN-CAI ${ }^{1}$, \\ GONG-KAN FENG ${ }^{2}, \mathrm{KE} \mathrm{DING}^{3}$, XIAO-FENG ZHU ${ }^{2}$ and ZHONG GUAN ${ }^{1}$
}

\begin{abstract}
${ }^{1}$ Department of Otorhinolaryngology-Head and Neck Surgery, Sun Yat-sen Memorial Hospital of Sun Yat-sen University, Guangzhou, Guangdong 510120; ${ }^{2}$ State Key Laboratory of Oncology in South China, Cancer Center, Sun Yat-sen University, Guangzhou, Guangdong 510275; ${ }^{3}$ Key Laboratory of Regenerative Biology and Institute of Chemical Biology, Guangzhou Institutes of Biomedicine and Health, Chinese Academy of Sciences, Guangzhou, Guangdong 510530, P.R. China
\end{abstract}

Received April 10, 2015; Accepted July 26, 2016

DOI: $10.3892 / 01.2016 .5088$

\begin{abstract}
Dysregulation of the discoidin domain receptors (DDRs) has been implicated in the development of numerous types of tumors, including head and neck cancer, and nasopharyngeal, breast, ovarian and esophageal carcinomas. Furthermore, agents that inhibit DDR1 activity are hypothesized to be useful for the treatment of nasopharyngeal carcinoma (NPC). The aim of the present study was to evaluate the effect of the DDR1 inhibitory (3-(2-(pyrazolo(1,5-a) pyrimidin-6-yl)-ethynyl)benzamide compound, 7RH, in NPC cells both in vitro and in vivo, and its effect when used in combination with dasatinib, a SRC family kinase (SFK) inhibitor. The effects of 7RH alone or in combination with dasatinib on cell viability were assessed using MTT assays and apoptosis was detected by flow cytometry. In addition, western blotting was performed to analyze the relative protein expression levels of cell cycle-associated genes in human NPC cell lines (CNE1, CNE2, HONE1 and SUNE1). Cell migration
\end{abstract}

Correspondence to: Professor Xiao-Feng Zhu, State Key Laboratory of Oncology in South China, Cancer Center, Sun Yat-sen University, 135 Xingang Xi Road, Guangzhou, Guangdong 510275, P.R. China

E-mail: zhuxf@sysucc.org.cn

Dr Zhong Guan, Department of Otorhinolaryngology-Head and Neck Surgery, Sun Yat-sen Memorial Hospital of Sun Yat-sen University, 107 Yanjiang Xi Road, Yuexiu, Guangzhou, Guangdong 510120, P.R. China

E-mail: gzhong@mail.sysu.edu.cn

Abbreviations: NPC, nasopharyngeal carcinoma; DDRs, discoidin domain receptors; RTK, receptor tyrosine kinase; siRNA, small interfering RNA; SFK, Src family kinase; HNSCC, head and neck squamous cell carcinoma

Key words: discoidin domain receptor 1 inhibitor, Janus kinase 1/signal transducer and activator of transcription 3, Src, dasatinib, nasopharyngeal carcinoma was also assessed using cell adhesion assays. Furthermore, tumor xenografts of CNE2 NPC cells were established in nude mice and the growth inhibitory effects of 7RH treatment alone or in combination with dasatinib were evaluated. Finally, knockdown of DDR1 protein expression was achieved by transfection of CNE2 cells with DDR1-specific small interfering RNA. Treatment with 7RH effectively suppressed the proliferation and induced the apoptosis of NPC cells. In addition, the Janus kinase 1 (JAK1)/signal transducer and activator of transcription (STAT3) signaling pathway was downregulated by $7 \mathrm{RH}$, whereas the activities of the Ras/Raf/mitogen-activated protein kinase kinase $(\mathrm{MEK}) /$ extracellular signal-regulated kinase (ERK) and phosphoinositide 3-kinase (PI3K)/AKT signaling pathways were upregulated in response to $7 \mathrm{RH}$ treatment. Furthermore, the expression levels of phosphorylated SRC were increased in NPC cells treated with 7RH; thus indicating that SRC exhibits a vital function in the resistance of NPC cells to 7RH via activation of the PI3K/AKT signaling pathway. The results of the present study indicate that DDR1 and SFK inhibition may present a potential therapeutic strategy for patients with NPC.

\section{Introduction}

Head and neck squamous cell carcinoma (HNSCC) is the fifth most common malignancy worldwide (1). Despite advances in the diagnosis and treatment of HNSCC, the 5-year survival rates for patients with HNSCC have remain unchanged at at $30-40 \%$ for the last 30 years. Furthermore, local and distant metastases remain significant barriers to disease eradication (1). Nasopharyngeal carcinoma (NPC) is a prevalent head and neck cancer in Southeast Asia, with an annual incidence rate of 54.7 cases per 100,000 individuals (2). NPC is unique among head and neck cancers due to its epidemiology, carcinogenic risk factors, biological markers, prognostic factors, clinical presentation, therapeutic strategies and outcome, as well as its close association with the Epstein-Barr virus and its high incidence of metastasis (3). 
An increasing number of studies have suggested that the majority of human cancers exhibit dysregulated expression and/or functioning of one or more receptor tyrosine kinases (RTKs) (4). The protein tyrosine kinases belong to a large, multigene family involved in the regulation of cell-to-cell signaling that is associated with cell growth, differentiation, adhesion, motility and apoptosis (4).

Discoidin domain receptors (DDRs) are a unique set of RTKs that exhibit an important function in cancer progression by regulating the interaction of tumor cells with their surrounding collagen matrix. DDRs, which are distinguished from other RTKs by the discoidin motif in their extracellular domain (5), are upregulated in a number of solid tumors, including head and neck cancer, and nasopharyngeal, breast, ovarian and esophageal carcinomas (6-18). According to the homology of the C-terminal region, DDRs may be divided into two categories: DDR1 and DDR2. The two categories of DDRs exhibit different tissue-specific expression patterns: DDR1 is predominantly expressed in epithelial cells and DDR2 is predominantly expressed in mesenchymal cells $(19,20)$. Previous studies have demonstrated that DDR1 and DDR2 exhibit vital functions in the regulation of fundamental cellular processes, including proliferation, survival, differentiation, adhesion and matrix remodeling $(21,22)$. In addition, the dysregulation of DDR1 and DDR2 has been associated with a number of human diseases, including fibrotic disorders, atherosclerosis and cancer $(5,23)$. In a previous study, inhibition of DDR1 using small interfering RNA (siRNA) was demonstrated to suppress tumorigenicity, inhibit lung cancer bone metastasis and increase cancer cell chemosensitivity (24). Therefore, DDR1 is considered a potential molecular target for cancer therapy.

SRC family kinases (SFKs), which are a family of non-RTKs, exhibit elevated protein expression levels in NPC cells (25). Activated SRC may in turn activate AKT, a key effector of the phosphoinositide 3-kinase (PI3K)/AKT/mammalian target of rapamycin (mTOR) pathway (26). In addition, AKT is an important component of signaling pathways that regulate proliferation, survival, metastasis and angiogenesis (27). Thus, due to its involvement in these oncogenic processes, AKT presents a potential therapeutic target for the treatment of cancer.

To the best of our knowledge, no previous studies have evaluated the effect of the DDR1 inhibitor in NPC cells. Since high levels of DDR1 protein have been identified in HNSCC tissues (6) and DDR1 transcripts are upregulated in NPC, NPC metastasis, and head and neck tumor tissues (7), we hypothesize that inhibition of DDR1 may be useful for the treatment of patients with NPC. Therefore, the present study aimed to investigate the effects of a (3-(2-(pyrazolo(1,5-a) pyrimidin-6-yl)-ethynyl)benzamide compound, 7RH (Fig. 1A), which is a potent and reversible small molecule inhibitor of DDR1 (28), on the proliferation and apoptosis of NPC cells, as well as the underlying mechanisms of such. In addition, the ability of 7RH to act synergistically with the SFK inhibitor, dasatinib, was evaluated.

\section{Materials and methods}

Materials and reagents. Human NPC cell lines (CNE1, CNE2, HONE1 and SUNE1) were obtained from the Cancer Center of Sun-Yat-sen University (Guangzhou, China) and cultured in RPMI-1640 medium supplemented with 5\% fetal bovine serum (FBS; Gibco; Thermo Fisher Scientific, Inc., Waltham, MA, USA), $100 \mathrm{U} / 1$ penicillin and $100 \mathrm{mg} / \mathrm{ml}$ streptomycin at $37^{\circ} \mathrm{C}$ in $5 \% \mathrm{CO}_{2}$. All experiments were performed using cells in the logarithmic phase. The DDR1 inhibitor, 7RH (Guangzhou Institutes of Biomedicine and Health, Chinese Academy of Sciences, Guangzhou, China) was dissolved in $50 \mathrm{mmol} / \mathrm{l}$ dimethyl sulfoxide (DMSO) and stored at $-20^{\circ} \mathrm{C}$. Dasatinib (Selleckchem, Co., Ltd., Houston, TX, USA) was dissolved in $50 \mathrm{mmol} / 1 \mathrm{DMSO}$ prior to storage at $-20^{\circ} \mathrm{C}$. Primary antibodies against DDR1 (catalog no. 3917; 1:1,000; rabbit), phosphorylated (p)-SRC (catalog no. 2105; 1:1,000; rabbit), SRC (catalog no. 2108; 1:1,000; rabbit), p-Janus kinase 1 (JAK1; catalog no. 3331; 1:1,000; rabbit), JAK1 (catalog no. 3332; 1:1,000; rabbit), p-AKT (Ser473; catalog no. 4060; 1:2,000; rabbit), p-glycogen synthase kinase $3 \beta$ (GSK3 $\beta$; catalog no. 5558; 1:1,000; rabbit), p-MEK (catalog no. 3958; 1:1,000; rabbit), MEK (catalog no. 9126; 1:1,000; rabbit), p-eukaryotic translation initiation factor $4 \mathrm{E}$ binding protein 1 (p-4EBP1; catalog no. 9456; 1:1,000; rabbit), 4EBP1 (catalog no. $9452 ; 1: 1,000 ;$ rabbit), poly(ADP-ribose) polymerase 1 (PARP; catalog no. 9544; 1:1,000; rabbit), E-cadherin (catalog no. 14472; 1:1,000; mouse), p-Pyk2 (catalog no. 3291; 1:1,000; rabbit), Pyk2 (catalog no. 3292; 1:1,000; rabbit), p-focal adhesion kinase (FAK; catalog no. 3284; 1:1,000; rabbit) and FAK (catalog no. 3285; 1:1,000; rabbit) were obtained from Cell Signaling Technology Inc. (Danvers, MA, USA). Primary antibodies against AKT (catalog no. sc-5298; 1:1,000; mouse), GSK3 $\beta$ (catalog no. sc-24501; 1:1,000; rabbit), p-extracellular signal-regulated kinase (p-ERK; catalog no. sc-7976; 1:1,000; rabbit), ERK (catalog no. sc-514302; 1:1,000; mouse), caspase-3 (catalog no. sc-65497; 1:1,000; mouse), myeloid cell leukemia-1 (MCL-1; catalog no. sc-12756; 1:1,000; mouse), B-cell lymphoma-2 (BCL-2; catalog no. sc-492; 1:1,000; rabbit), cyclin-dependent kinase 4 (CDK4; catalog no. sc-260; 1:1,000; rabbit), cyclin D1 (catalog no. sc-450; 1:1,000; mouse), P21 (catalog no. sc-6246; 1:1,000; mouse), c-Myc (catalog no. sc-789; 1:1,000; rabbit), signal transducer and activator of transcription 3 (STAT3; catalog no. 12640; 1:1,000; rabbit), p-STAT3 (catalog no. 9145; 1:2,000; rabbit) and glyceraldehyde 3-phosphate dehydrogenase (catalog no. sc-365062; 1:2,000; mouse) were purchased from Santa Cruz Biotechnology, Inc. (Dallas, TX, USA). The secondary antibodies, anti-rabbit immunoglobulin $\mathrm{G}$ ( $\mathrm{IgG})$, horseradish-peroxidase (HRP)-linked antibody (catalog no. 7074; 1:2,000) and antimouse IgG, HRP-linked antibody (catalog no. 7076; 1:2,000), were obtained from Cell Signaling Technology, Inc.

MTT assay. NPC cells in the logarithmic phase were seeded into 96-well plates at a density of 1,500 cells per well in $195 \mu \mathrm{l}$ RPMI-1640 medium and cultured at $37^{\circ} \mathrm{C}$ overnight. Subsequently, the cells were treated with various concentrations $(0.625,1.25,2.5,5,10$ and $20 \mu \mathrm{mol} / 1)$ of $7 \mathrm{RH}$ and/or dasatinib for $72 \mathrm{~h}$ at $37^{\circ} \mathrm{C}$ in $5 \% \mathrm{CO}_{2}$. Control cells were treated in the same manner as the treatment group but without $7 \mathrm{RH}$ or dasatinib. Experiments were terminated by adding $10 \mu \mathrm{l}$ of $5 \mathrm{mg} / \mathrm{ml} \mathrm{MTT}$ and incubated at $37^{\circ} \mathrm{C}$ for $4 \mathrm{~h}$. Following complete removal of the medium, $100 \mu 1$ DMSO was added to each well to dissolve the purple formazan product. The 
optical densities (ODs) of the resultant purple solutions were measured at an absorbance wavelength of $570 \mathrm{~nm}$. The half maximal inhibitory concentration $\left(\mathrm{IC}_{50}\right)$ was calculated using the following equation: Inhibitory rate $(\%)=(1-$ mean OD value of the treatment group / mean OD value of the control group) x 100 .

Western blot analysis. Prior to drug treatment, CNE2 cells were seeded into 6-well plates at a density of $3 \times 10^{5}$ cells per well and incubated at $37^{\circ} \mathrm{C}$ in $5 \% \mathrm{CO}_{2}$ overnight. Following treatment, CNE2 cells were collected and washed three times with $1 \mathrm{X}$ phosphate-buffered saline (PBS) and lysed using $100 \mu 1$ lysis buffer (Cell Signaling Technology, Inc.) per well. Cell lysates were centrifuged at $13,439 \mathrm{x}$ g for $15 \mathrm{~min}$ at $4^{\circ} \mathrm{C}$ and protein concentrations were determined using the Bio-Rad Protein Assay (Bio-Rad Laboratories, Inc., Hercules, CA, USA). SDS-PAGE loading buffer was added to the cell lysates, which were then heated at $100^{\circ} \mathrm{C}$ for $10 \mathrm{~min}$. Equal quantities of protein $(24 \mu \mathrm{g})$ were separated by 10 and $15 \%$ SDS-PAGE and the resolved proteins were transferred onto polyvinylidene difluoride membranes. After blocking with 5\% skimmed milk, the membranes were incubated sequentially with the primary and secondary antibodies overnight at $4^{\circ} \mathrm{C}$. After washing three times with Tris-buffered saline supplemented with Tween-20 (pH 7.4; 10 mmol/l Tris- $\mathrm{HCl}, 150$ mmol/1 NaCl, $0.1 \%$ Tween 20 ), the proteins were detected using enhanced chemiluminescence reagent (EMD Millipore, Billerica, MA, USA) and BioMax ${ }^{\circledR}$ XAR film (Kodak, Rochester, NY, USA). Band intensities were analyzed using ImageJ software (version 1.45; National Institutes of Health, Bethesda, MA, USA).

Cell apoptosis analysis by flow cytometry. Cell apoptosis was assessed by measuring the membrane redistribution of phosphatidylserine using an Annexin V-FITC Apoptosis Detection kit (Roche, Basel, Switzerland), according to the manufacturer's instructions. Briefly, cells (1x10\%/well) were seeded into 6-well plates and allowed to attach overnight. Subsequently, the cells were treated with 2, 4 or $8 \mu \mathrm{mol} / 17 \mathrm{RH}$ for $48 \mathrm{~h}$, washed twice with PBS, resuspended in $250 \mu \mathrm{l}$ binding buffer and stained with Annexin V-FITC and propidium iodide. Following incubation in the dark for $30 \mathrm{~min}$, the cells were analyzed using the BD FACSCalibur flow cytometer (BD Biosciences, Franklin Lakes, NJ, USA).

Colony formation assays. To assess colony formation, 200 CNE2 or HONE1 cells were seeded into each well of a 6 -well plate in replicates. After $24 \mathrm{~h}$, the cells were incubated with or without $7 \mathrm{RH}(0,0.4,0.6$ and $0.8 \mu \mathrm{mol} / 1)$ in $5 \% \mathrm{FBS}$ at $37^{\circ} \mathrm{C}$ and allowed to grow for 5 days. At the end of the treatment period, the cells were fixed with $100 \%$ ethanol, stained with $0.1 \%$ crystal violet and washed with distilled water. Images of the colonies were captured with an inverted microscope and quantification was performed using ImageJ software (National Institutes of Health).

Cell adhesion assays. Cells in the logarithmic phase were seeded into 6 -well plates at a density of $3 \times 10^{5}$ cells per well in RPMI-1640 medium containing 5\% FBS and cultured at $37^{\circ} \mathrm{C}$ overnight. Subsequently, the cells were treated with various concentrations $(0,2,4$ and $8 \mu \mathrm{mol} / \mathrm{l})$ of $7 \mathrm{RH}$ and/or dasatinib for $24 \mathrm{~h}$ at $37^{\circ} \mathrm{C}$ in $5 \% \mathrm{CO}_{2}$, while 96 -well plates were precoated with BD Matrigel (BD Biosciences) at $37^{\circ} \mathrm{C}$ for $2 \mathrm{~h}$. Single cell suspensions were prepared in RPMI-1640 medium containing $5 \%$ FBS, and seeded into the 96-well plates with DMSO control or $7 \mathrm{RH}$ at a density of $1 \times 10^{5}$ cells/well. Following $2 \mathrm{~h}$ of incubation at $37^{\circ} \mathrm{C}$, the cells were washed with PBS to remove the nonadherent cells. To obtain the adherent cell number, adherent cells were extracted using $200 \mu \mathrm{l}$ MTT and the absorbance at $570 \mathrm{~nm}$ was measured.

siRNA transfection. Prior to transfection, the cells were seeded into 6-well plates with antibiotic-free growth medium (Gibco; Thermo Fisher Scientific, Inc.) at a density of $2.5 \times 10^{5}$ cells per well and cultured overnight at $37^{\circ} \mathrm{C}$. At $\sim 50 \%$ confluence, the cells were transfected with DDR1-specific siRNA (DDR1 \#1 sense, 5'-CCACCAACUUCAGCAGCUUTT-3' and antisense, 5'-AAGCUGCUGAAGUUGGUGGTT-3'; DDR1 \#2 sense, 5'-GGUUACUCUUCAGCGAAAUTT-3' and antisense, 5'-AUUUCGCUGAAGAGUAACCTT-3'; and control sense, 5'-UUCUCCGAACGUGUCACGUTT-3' and antisense, 5'-ACGUGACACGUUCGGAGAATT-3') in Opti-MEM ${ }^{\circledR}$ reduced serum medium (Gibco; Thermo Fisher Scientific, Inc.) using Lipofectamine ${ }^{\circledR} 2000$ (Gibco; Thermo Fisher Scientific, Inc.), according to the manufacturer's instructions. After 4-6 h, the medium was replaced with fresh RPMI-1640 medium containing 5\% FBS and cells were cultured for another $24 \mathrm{~h}$.

Animals. A total of 24 male BALB/c nude mice (age, 6 weeks; weight, $20 \pm 2 \mathrm{~g}$ ) were obtained from the Guangdong Province Animal Facility (Sun Yat-sen University) and provided with distilled water and a commercial stock diet in an air-conditioned room at $22^{\circ} \mathrm{C}$. All animals were sacrificed by cervical dislocation following anesthetization with ethyl ether (Sigma-Aldrich; EMD Millipore). The present study was approved by the Institutional Animal Care and Use Committee of Guangdong Medical Laboratory Animal Center (Guangdong, China). All animal studies were performed in accordance with the National Institutes of Health Guide for the Care and Use of Laboratory Animals (29).

Mouse tumor xenograft model. CNE2 cells $\left(1.3 \times 10^{6}\right.$ cells per $0.2 \mathrm{ml}$ PBS) were injected subcutaneously into the right armpit of nude mice. Tumor size was measured every 4 days in two dimensions using a caliper and tumor volumes were calculated using the formula: $a b^{2} / 2$, where $b$ is the smaller dimension. When tumors reached $\sim 150 \mathrm{~mm}^{3}$ in size, the mice were randomized into four groups (6 mice/group), as follows: i) Normal saline (NS) group, intraperitoneally injected with NS for 20 days; ii) 7RH group, intraperitoneally injected with $8 \mathrm{mg} / \mathrm{kg} 7 \mathrm{RH}$ for 20 days; iii) dasatinib group, intraperitoneally injected with $10 \mathrm{mg} / \mathrm{kg}$ dasatinib for 20 days; and iv) $7 \mathrm{RH}+$ dasatinib group, intraperitoneally injected with $8 \mathrm{mg} / \mathrm{kg} 7 \mathrm{RH}$ and $10 \mathrm{mg} / \mathrm{kg}$ dasatinib for 20 days.

Tumor inhibition rate. The inhibitory effect of $7 \mathrm{RH}$ and/or dasatinib on tumor growth was evaluated. After 20 days of treatment, the mice were anesthetized with ethyl ether and sacrificed via cervical dislocation and the whole body and tumor mass were weighed immediately. The inhibition rates of solid tumor growth were calculated using the following formula: Inhibition 
A

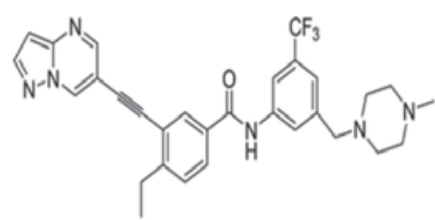

C

CNE2

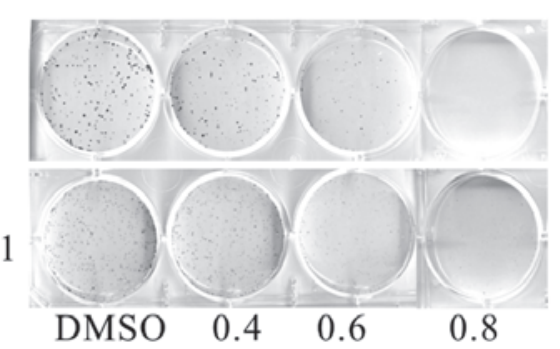

$7 \mathrm{RH}$ concentration $(\mu \mathrm{mol} / \mathrm{l})$

D

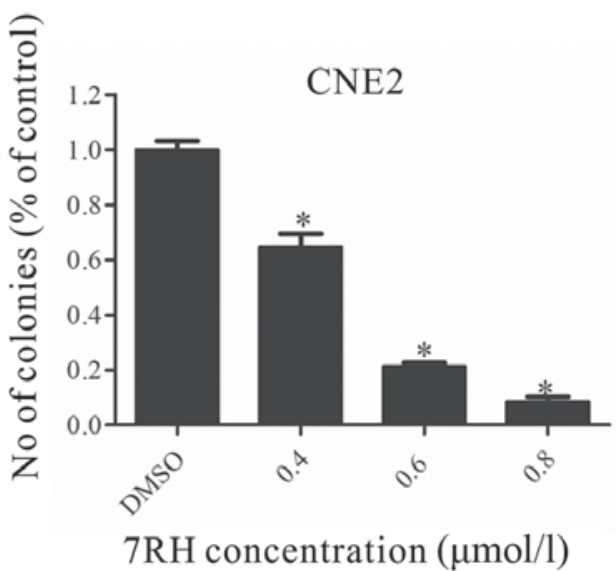

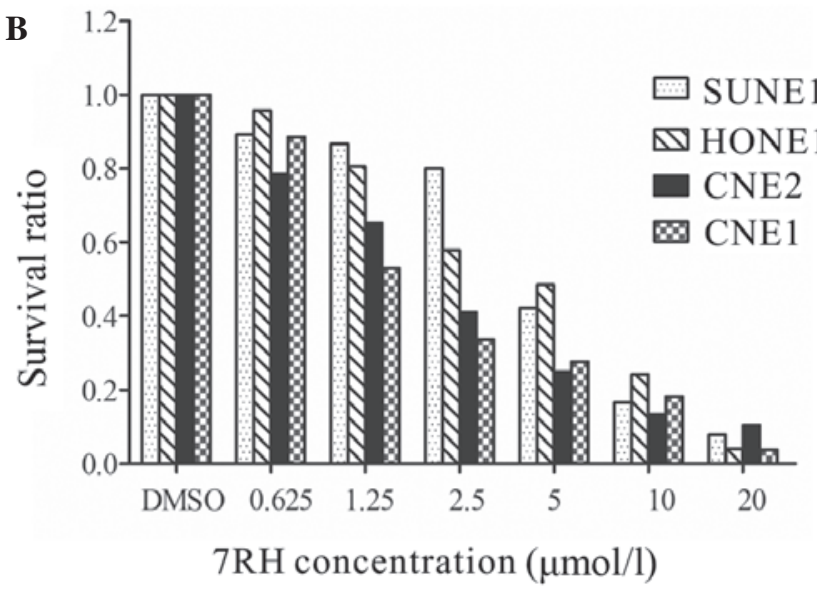

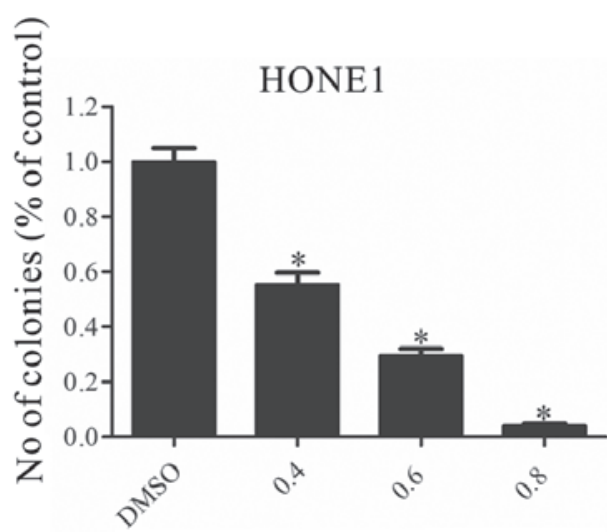

$7 \mathrm{RH}$ concentration $(\mu \mathrm{mol} / \mathrm{l})$

Figure 1. 7RH inhibited the proliferation and colony formation of nasopharyngeal carcinoma cells. (A) Structure of the (3-(2-(pyrazolo(1,5-a)pyrimidin-6-yl)-ethynyl)benzamide compound, 7RH. (B) SUNE1, HONE1, CNE2 and CNE1 cells were treated with 0, 0.625, 1.25, 2.5, 5, 10 or 20 $\mu$ mol/1 7RH for $72 \mathrm{~h}$, after which the antiproliferative effect of 7RH was measured using MTT assays. Cell proliferation was decreased in a dose-dependent manner following treatment with $7 \mathrm{RH}$ in all cell lines. (C) The colony forming abilities of CNE2 and HONE1 cells were decreased in a dose-dependent manner following treatment with $0.4,0.6$ and $0.8 \mu \mathrm{mol} / 17 \mathrm{RH}$ and (D) quantified using Image J software. Data are presented as the mean \pm standard deviation of triplicate experiments. ${ }^{*} \mathrm{P}<0.05$ vs. DMSO. DMSO, dimethyl sulfoxide.

rate $(\%)=(1-$ mean tumor volume of drug treated groups/mean tumor volume of NS group) x 100 . The $\mathrm{IC}_{50}$ and $\mathrm{CI}$ values were calculated with CalcuSyn software (Biosoft, Cambridge, UK).

Statistical analysis. Data are presented as the mean \pm standard deviation. To determine significant differences between the treatment and control groups, the Student's two-tailed t-test was used. SPSS 19.0 (IBM SPSS, Armonk, NY, USA) was used for the analyses. $\mathrm{P}<0.05$ was considered to indicate a statistically significant difference.

\section{Results}

7RH inhibits NPC cell proliferation and colony formation in vitro. To investigate the cytotoxicity of the DDR1 inhibitor 7RH in cancer cells, MTT assays were performed (Fig. 1B). 7RH exhibited potent cytotoxicity in NPC cell lines (CNE2, HONE1, CNE1 and SUNE1). Exposure to 7RH (0.625-20 $\mu \mathrm{mol} / \mathrm{l})$ resulted in a dose-dependent inhibition of cell viability. The $\mathrm{IC}_{50}$ values were 1.97, 3.71, 2.06 and $3.95 \mu \mathrm{mol} / 1$ in CNE2, HONE1, CNE1 and SUNE1 cells, respectively. These results indicate that 7RH inhibits NPC cell proliferation in a dose-dependent manner. In addition, it was observed that treatment with 0.4 , 0.6 and $0.8 \mu \mathrm{mol} / 1$ 7RH significantly inhibited colony formation in CNE2 and HONE1 cells ( $\mathrm{P}<0.05$; Fig. $1 \mathrm{C}$ and $\mathrm{D})$. Taken together, these results suggest that treatment $7 \mathrm{RH}$ effectively inhibits the tumorigenicity of NPC cells.

7RH induces cell cycle arrest and apoptosis by inhibiting JAK/STAT signaling in NPC cells. A previous study demonstrated that the STAT family (STAT1a/b, STAT3 and STAT5) directly bind to the DDR1 protein (5). Therefore, the present study aimed to investigate whether 7RH affects JAK/STAT signaling, which is involved in cell cycle progression, by analyzing the protein expression levels of key genes involved in this pathway. Following treatment with $4 \mu \mathrm{mol} / 7 \mathrm{RH}$ for 12,24 or $48 \mathrm{~h}$, the protein expression levels of JAK1, p-JAK1, STAT3, p-STAT3, BCL-2, MCL-1, c-Myc, cyclin D1 and CDK4 were markedly reduced in a time-dependent manner, whereas those of p21 were markedly increased in CNE2 cells (Fig. 2A). These results indicate that $7 \mathrm{RH}$ is able to effectively induce the cell cycle arrest of NPC cells. 


\section{A}

\begin{tabular}{rrrr} 
CNE2 & $7 \mathrm{RH} \quad 4 \mu \mathrm{mol} / \mathrm{l}$ \\
\hline 0 & $12 \mathrm{~h} \quad 24 \mathrm{~h}$ & $48 \mathrm{~h}$
\end{tabular}

DDR1

JAK 1

$\begin{array}{lllll}1 & 0.78 & 0.34 & 0.28\end{array}$

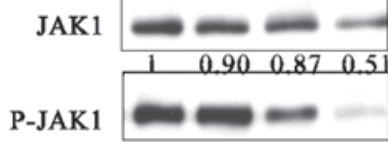

Stat3
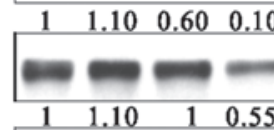

P-Stat3

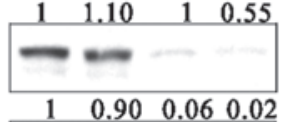

C-myc

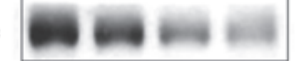

$\begin{array}{llll}1 & 0.77 & 0.42 & 0.29\end{array}$

CDK4

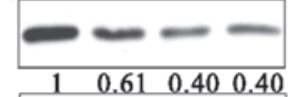

CyclinD1

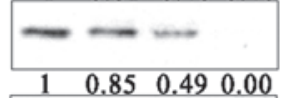

P21

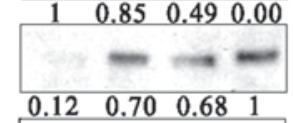

GAPDH

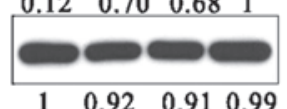

C

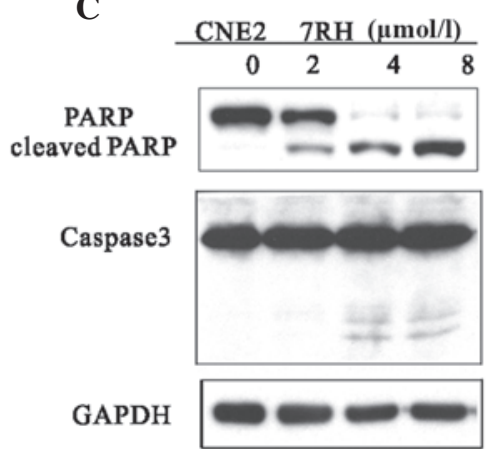

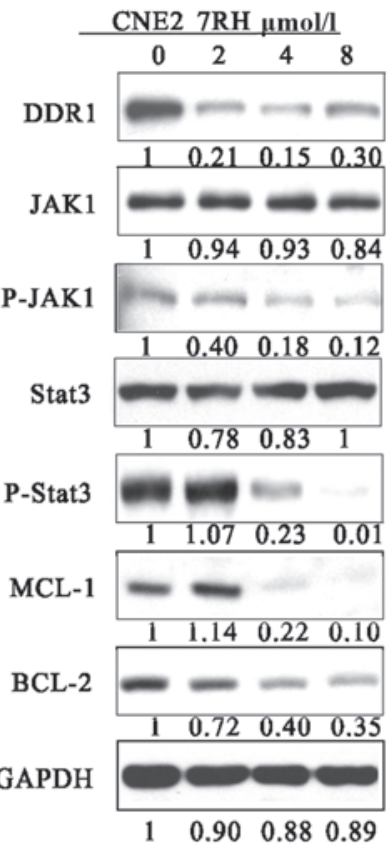

B

CNE2 SiRNA DDR1

NC \#1 NC \#2

DDR

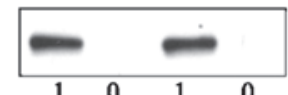

JAK 1

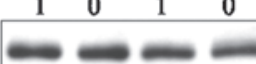

P-JAK1
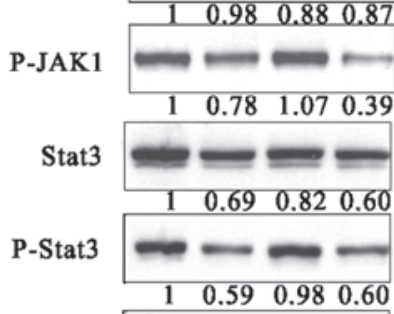

C-myc

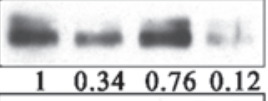

GAPDH

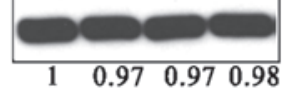

DMSO

D

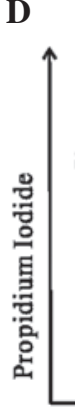

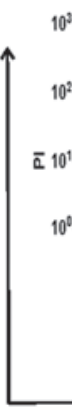

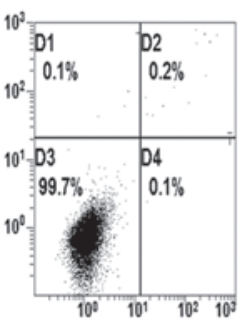

AnnexinV

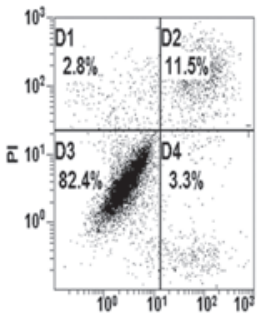

AnnexinV
7RH $(\mu \mathrm{mol} / \mathrm{l})$

4

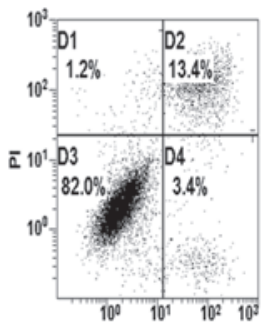

AnnexinV

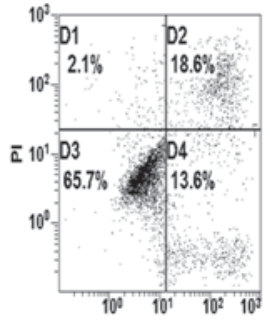

AnnexinV

Figure 2.7RH induced cell cycle arrest and apoptosis of CNE2 cells by inhibiting the JAK1-STAT3 signaling pathway. (A) The effect of 7RH on the cell cycle progression of CNE2 cells. CNE2 cells were incubated for 12, 24 or $48 \mathrm{~h}$ with $4 \mu \mathrm{mol} / 17 \mathrm{RH}$ or treated with $2,4 \mathrm{or} 8 \mu \mathrm{mol} / 17 \mathrm{RH}$ for $24 \mathrm{~h}$, after which the cell cycle profile was analyzed by western blotting. (B) Transfection of CNE2 cells with DDR1-specific siRNA was associated with similar alterations to the JAK1/STAT3 signaling pathway as observed following treatment of the cells with 7RH, as determined by western blotting. (C) Western blot analysis of cleaved PARP and caspase-3. CNE2 cells were treated with 2, 4 or $8 \mu \mathrm{mol} / 17 \mathrm{RH}$ for 24 (PARP) or $48 \mathrm{~h}$ (caspase-3). (D) Induction of apoptosis in cells following 7RH treatment was assessed by flow cytometry using an Apoptosis Detection kit. The apoptotic rates of the cell lines were increased following treatment with 2 , 4 or $8 \mu \mathrm{mol} / 1$ 7RH for $48 \mathrm{~h}$. JAK1, Janus kinase 1; p-, phosphorylated; STAT3, signal transducer and activator of transcription 3; DDR1, discoidin domain receptor 1; siRNA, small interfering RNA; DMSO, dimethyl sulfoxide.

Transfection of CNE2 cells with DDR1-specific siRNA was performed to investigate the effect of DDR1 inhibition on the activation of the JAK/STAT signaling pathway (Fig. 2B). When DDR1 was knocked out by siRNA, the expressions of JAK1, p-JAK1, STAT3, p-STAT3 and c-Myc was reduced. In addition, to further investigate the mechanism of growth inhibition by $7 \mathrm{RH}$, the effect of 7RH on the apoptosis of CNE2 cells was evaluated by western blotting and flow cytometry (Fig. 2C and D). 7RH induced the apoptosis of CNE2 cells, as indicated by the increased levels of PARP cleavage and caspase- 3 activation observed following treatment with 2,4 or $8 \mu \mathrm{mol} / 17 \mathrm{RH}$ for 24 or $48 \mathrm{~h}$ (Fig. 2C). The western blot analysis results were correlated with a higher fraction of Annexin-V-positive cells at $48 \mathrm{~h}$ (Fig. 2D). These results indicate that 7RH induces cell cycle arrest and apoptosis of NPC cells via alteration of the JAK/STAT signaling pathways.

7RH inhibits NPC cell adhesion. Cell adhesion is involved in a number of regulatory processes, including growth, differentiation, proliferation, migration and regeneration (30). In addition, adhesion exhibits a crucial function in the formation and maintenance of coherent multicellular structures. DDR1 has previously been demonstrated as one of the key regulators of cell adhesion (31). Therefore, the present study investigated the effect of 7RH on cell-matrix adhesion by performing western blot analysis of cell adhesion-associated proteins and adhesion assays. As shown in Figure 3A, the protein expression levels of E-cadherin, p-Pyk2 and p-FAK were markedly decreased in CNE2 cells 

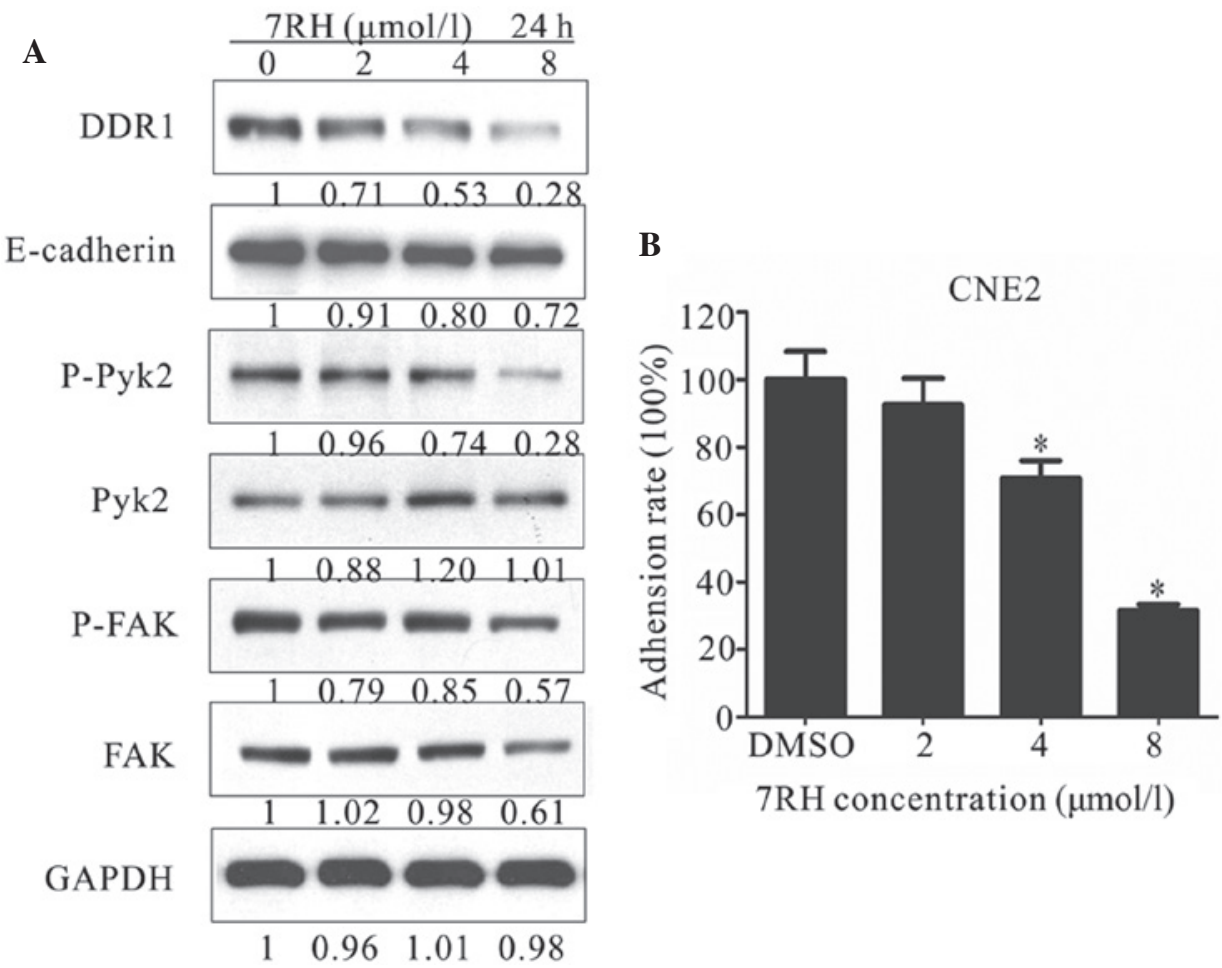

Figure 3.7RH inhibited adhesion in CNE2 cells. (A) Effect of 7RH on the expression of cell adhesion-associated proteins in CNE2 cells. The cells were treated with 2, 4 or $8 \mu \mathrm{mol} / 17 \mathrm{RH}$ for $24 \mathrm{~h}$, after which the cell adhesion profile was analyzed by western blotting. (B) The cell adhesion ratio of CNE2 cells decreased in a dose-dependent manner following treatment with 2,4 or $8 \mu \mathrm{mol} / 17 \mathrm{RH}$, as quantified using ImageJ software. Data are presented as the mean \pm standard deviation of triplicate experiments ${ }^{*} \mathrm{P}<0.05$ vs. DMSO. DDR1, discoidin domain receptor 1; FAK, focal adhesion kinase; DMSO. DMSO, dimethyl sulfoxide.

following treatment with 2, 4 or $8 \mu \mathrm{mol} / 1 \mathrm{RH}$ for $24 \mathrm{~h}$. For adhesion assays, CNE2 cells adhering to BD Matrigel-coated wells were treated with 2,4 or $8 \mu \mathrm{mol} / 17 \mathrm{RH}$ for $2 \mathrm{~h}$ and the number of adherent cells was determined by measuring the absorbance at $570 \mathrm{~nm}$. Notably, 7RH inhibited cell-matrix adhesion in a dose-dependent manner (Fig. 3B) and this inhibition was significant following treatment with 4 or $8 \mu \mathrm{mol} / 17 \mathrm{RH}$ $(\mathrm{P}<0.05)$. Treatment with 2,4 or $8 \mu \mathrm{mol} / 1 \mathrm{RH}$ for $2 \mathrm{~h}$ inhibited cell-matrix adhesion by $7.4,29.3$ and $68.3 \%$, respectively, in CNE2 cells, compared with DMSO-treated controls (Fig. 3B). These results indicate that 7RH inhibits NPC cell adhesion.

7RH enhances the PI3K/AKT signaling pathway via activation of SRC in NPC cells. To further investigate the mechanism of growth inhibition by $7 \mathrm{RH}$, the effect of $7 \mathrm{RH}$ on the PI3K/AKT and mitogen-activated protein kinase (MAPK) signaling pathways were investigated. Western blot analysis indicated that the expression levels of p-AKT (Ser473), p-GSK $3 \beta$ and p-MEK were significantly upregulated in CNE2 cells following treatment with 2,4 or $8 \mu \mathrm{mol} / 1 \mathrm{RH}$ for $24 \mathrm{~h}$ (Fig. 4A). Activated SRC is a potent activator of the PI3K/AKT signaling pathway (27). Therefore, the present study aimed to elucidate whether PI3K/AKT signaling was upregulated by SRC signaling. Notably, the protein expression levels of $\mathrm{p}-\mathrm{SRC}$ were markedly upregulated following the inhibition of DDR1 with both 7RH and DDR1-specific siRNA (Fig. 4B and C). These results indicate that $7 \mathrm{RH}$ enhances the PI3K/AKT signaling pathway in NPC cells via the activation of SRC.

Dual inhibition of DDRI and SFK decreases the tumorigenicity of NPC cells in vitro. Subsequently, whether the combined inhibition of DDR1 and SFKs exhibited a synergistic effect on cell tumorigenicity was investigated. Firstly, the combined inhibitory effect of 7RH and dasatinib on cell proliferation was examined using MTT assays. The proliferation of CNE2 cells was significantly inhibited following treatment with 7RH in combination with various concentrations of dasatinib in a dose-dependent manner. The corresponding combination indexes (CIs) were $<1$ for CNE2 cells, which were determined to be statistically significant (Table I). These results suggest that combined treatment with 7RH and dasatinib exhibits a synergistic effect on the suppression of human NPC cell proliferation.

To investigate the combined effect of $7 \mathrm{RH}$ and dasatinib on the PI3K/AKT signaling pathway, the protein expression levels of key proteins in this signaling pathway in CNE2 cells were evaluated in CNE2 cells by western blotting. Notably, dual inhibition of DDR1 and SFK following treatment with $4 \mu \mathrm{M} 7 \mathrm{RH}$ and $5 \mu \mathrm{M}$ dasatinib markedly decreased the protein expression of p-AKT (Ser473) compared with the groups of $7 \mathrm{RH}$ or dasatinib alone (Fig. 5A); however, no evident alterations in the expression levels of $\mathrm{p}-\mathrm{GSK} 3 \beta$ and $\mathrm{p}-\mathrm{MEK}$ were observed between the dual treatment of 7RH + dasatinib and 7RH or dasatinib alone (data not shown). In addition, the phosphorylation levels of one of the essential substrates of mTORC1, 4EBP1, as well as p-ERK, were significantly suppressed following combined treatment with $4 \mu \mathrm{M} 7 \mathrm{RH}$ and $5 \mu \mathrm{M}$ dasatinib (Fig. 5A). These results indicated that the mTOR/4EBP1 and MAPK signaling pathways were significantly suppressed following treatment with 7RH and dasatinib in CNE2 cells. Furthermore, the induction of PARP and caspase- 3 cleavage and the decrease in the 

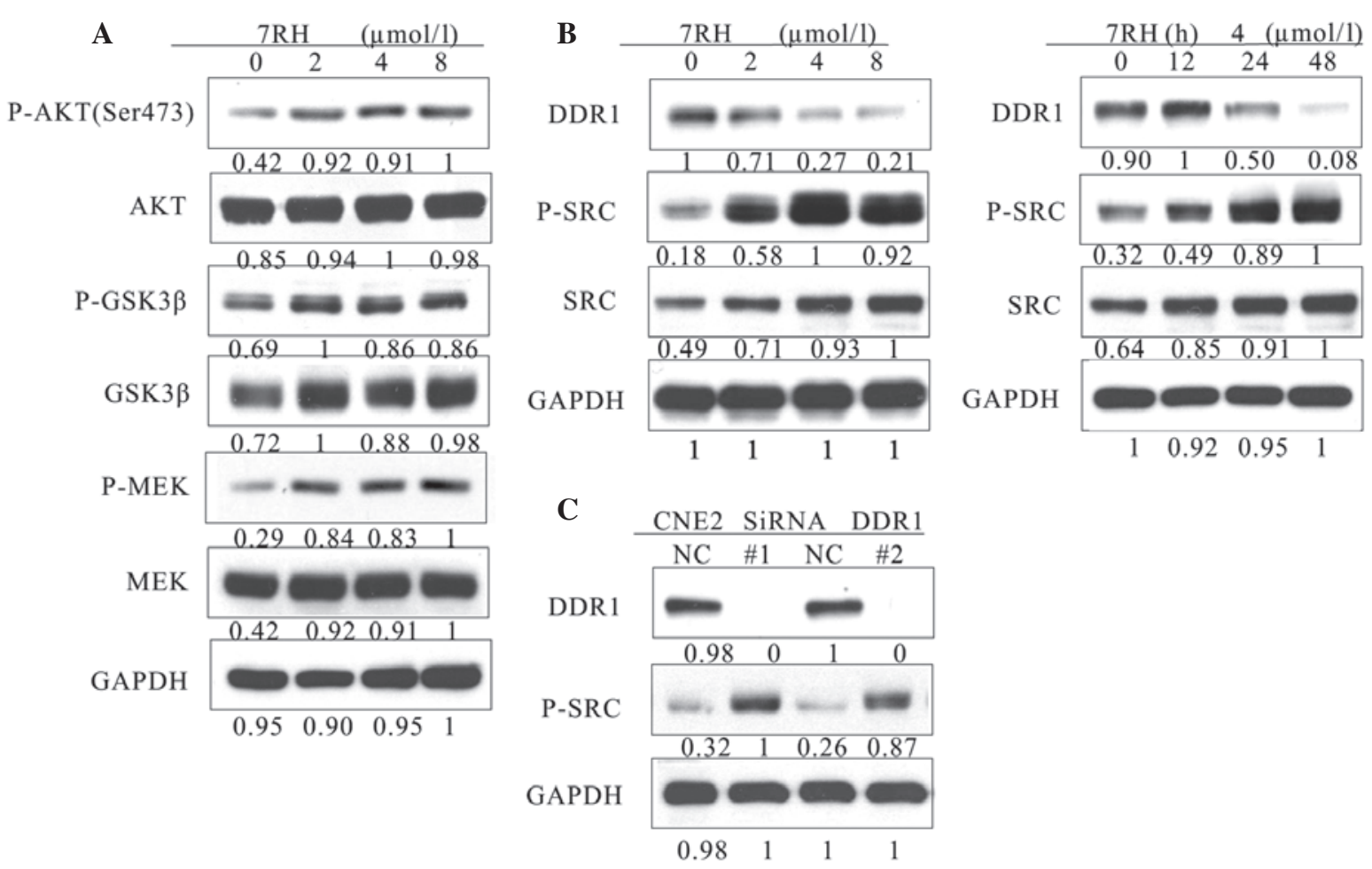

Figure 4. 7RH upregulated the PI3K/AKT pathway by activating SRC in CNE2 cells. (A) 7RH enhanced the activity of the PI3K/AKT signaling pathway. CNE2 cells were treated with 2, 4 or $8 \mu \mathrm{mol} / 17 \mathrm{RH}$ for 24 followed by western blotting of cell lysates to analyze phosphorylation levels of AKT (Ser473), GSK3 $\beta$ and MEK, relative to GAPDH. (B) 7RH treatment increased the phosphorylation of SRC in a time- and dose-dependent manner. CNE2 cells were treated with 2,4 or $8 \mu \mathrm{mol} / 17 \mathrm{RH}$ for $24 \mathrm{~h}$, or with $4 \mu \mathrm{mol} / 17 \mathrm{RH}$ for 12,24 or $48 \mathrm{~h}$, followed by western blotting to assess protein expression levels of DDR1, SRC and p-SRC. (C) CNE2 cells were transfected with siRNA-specific DDR1 for $24 \mathrm{~h}$ followed by western blotting to analyze the expression levels of DDR1

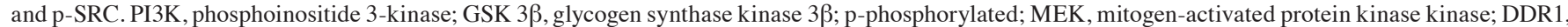
discoidin domain receptor 1 .

expression levels of MCL-1 and BCL-2 observed (Fig. 5A), correlated with a higher fraction of Annexin-V-positive cells following $48 \mathrm{~h}$ of treatment $(4 \mu \mathrm{M} 7 \mathrm{RH}$ and/or $5 \mu \mathrm{M}$ dasatinib; Fig. 5B), and indicated the effective induction of apoptosis in NPC cells. Furthermore, the dual inhibition of DDR1 and SFK significantly decreased NPC cell adhesion rate $(\mathrm{P}<0.05$; Fig. $5 \mathrm{C})$. Together, these results suggest that combined treatment with 7RH and dasatinib more effectively inhibits NPC cell tumorigenicity when compared with either drug alone.

Dual inhibition of DDR1 and SFK suppresses tumor growth in vivo. To determine whether treatment with $7 \mathrm{RH}$ and dasatinib exhibits synergistic effects in vivo, CNE2 cells were implanted into the right armpit of mice, which were divided into $\mathrm{NC}, 7 \mathrm{RH}$, dasatinib or $7 \mathrm{RH}+$ dasatinib treatment groups. Following 20 days of treatment, the mice were sacrificed and the mean tumor volumes were measured. The mean tumor volumes were significantly decreased in the treatment groups when compared with the $\mathrm{NC}$ group $(\mathrm{P}<0.05$; Fig. 6). In the $7 \mathrm{RH}$, dasatinib and 7RH + dasatinib groups, the growth inhibitory rates were 27, 28 and 33\%, respectively (Fig. 6).

\section{Discussion}

The present study demonstrated that $7 \mathrm{RH}$, a highly potent inhibitor of DDR1, effectively suppresses the tumorigenicity of NPC cells. This is consistent with the observation that DDR1 transcripts are upregulated in NPC, NPC metastasis, and head and neck tumor tissues (7). Furthermore, these results are consistent with a previous study that reported that inhibition of DDR1 by siRNA suppressed tumorigenicity, inhibited lung cancer bone metastasis and increased cancer cell chemosensitivity (24).

The results of the present study indicated that treatment with 7RH alone inhibited the proliferation of NPC cells in a dose-dependent manner. However, the exact mechanism underlying the effects of $7 \mathrm{RH}$ on cancer cells remains unclear. In human breast and colon carcinoma cell lines, DDR1 activation triggers the pro-survival Ras/Raf/ERK and PI3K/AKT signaling pathways, resulting in the upregulation of anti-apoptotic Bcl-xL and the promotion of survival under conditions of genotoxic stress (32). In colon cancer cells, DDR1 forms a complex with Notch1; DDR1 activation triggers Notch1 cleavage by $\gamma$-secretase, generating the Notch1 intracellular domain, which translocates into the nucleus and upregulates the expression of pro-survival genes, including Hes1 and Hey2 (33). The results of the present study indicated that 7RH-mediated inhibition of NPC cell growth may be due to inhibition of the JAK/STAT3 signaling pathway. This hypothesis was based on the observation that $7 \mathrm{RH}$ inhibited JAK and STAT3 phosphorylation in a time- and dose-dependent manner, which was also observed following treatment of NPC cells with DDR1-specific siRNA. Activation of the JAK-cytokine receptor complex leads to the recruitment and phosphorylation of specific cytoplasmic STAT proteins, which 
A

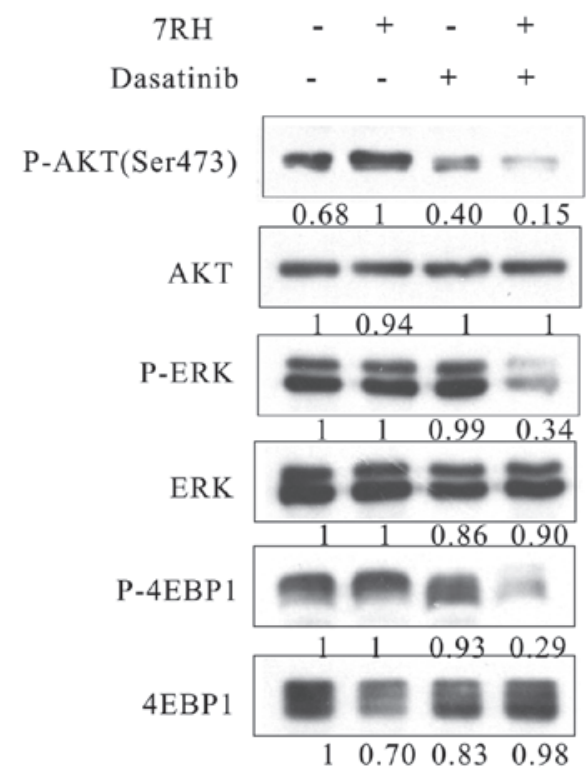

B

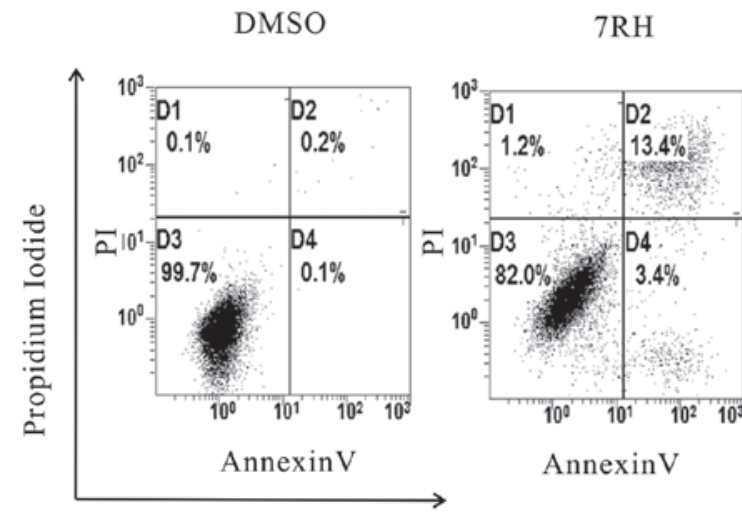

AnnexinV-FITC

C

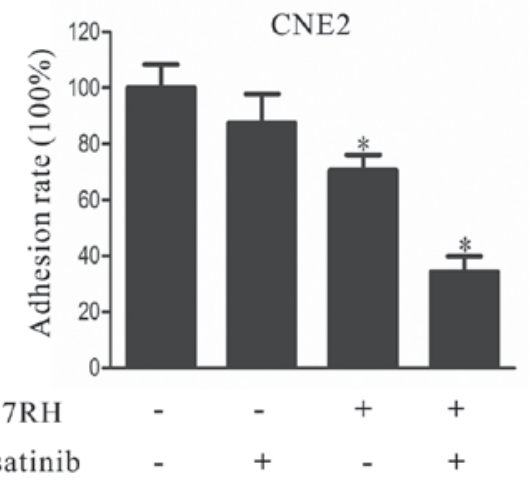

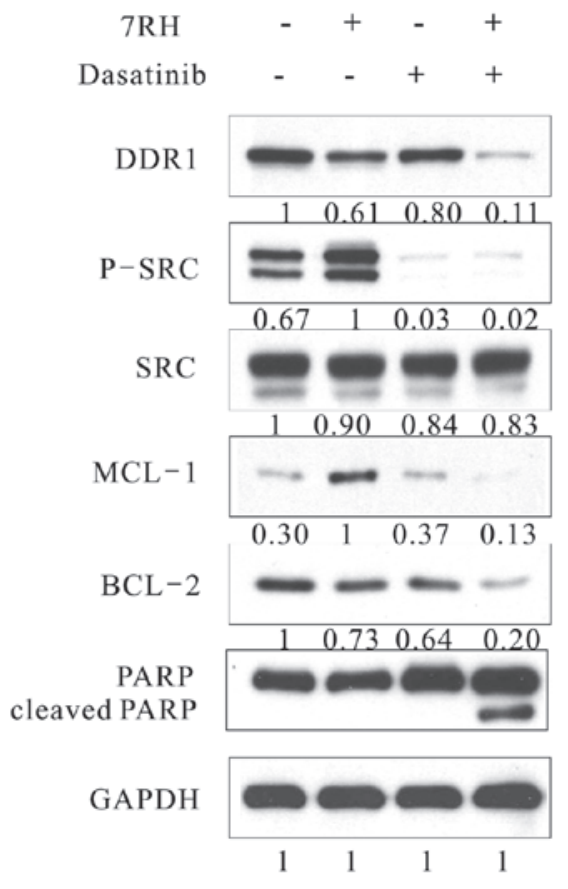

Dasatinib

$7 \mathrm{RH}+$ Dasatinib
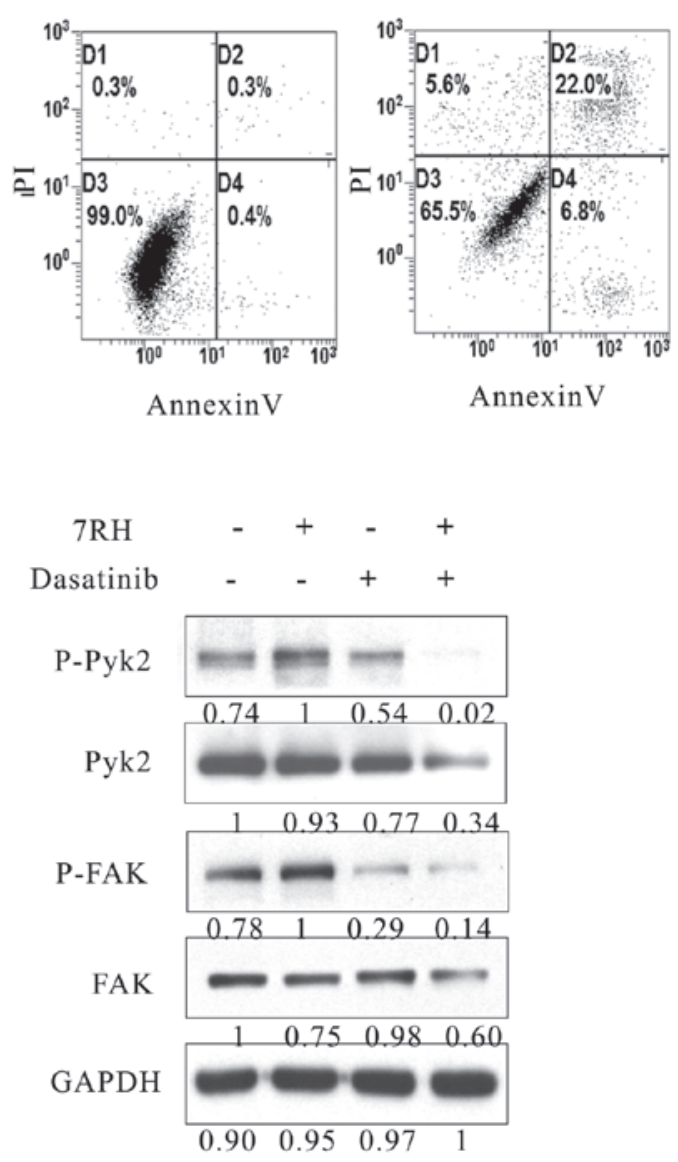

Figure 5. Dual inhibition of DDR1 and SFK decreased the tumorigenecity of NPC cells in vitro. (A) Effect of combined 7RH and dasatinib treatment on the survival, progression and apoptosis of CNE2 cells. (A) CNE2 cells were treated with $4 \mu \mathrm{M} 7 \mathrm{RH}$ alone, $5 \mu \mathrm{M}$ dasatinib alone or $7 \mathrm{RH} \pm$ dasatinib and the expression levels of cell cycle-associated proteins were analyzed by western blotting. (B) The apoptosis of NPC cells treated with $4 \mu \mathrm{M} 7 \mathrm{RH}$ and/or $5 \mu \mathrm{M}$ dasatinib for $48 \mathrm{~h}$ and stained with Annexin $\mathrm{V}$ and propidium iodide was analyzed using flow cytometry. The apoptosis rates of the cells treated with $7 \mathrm{RH} \pm$ dasatinib were increased when compared with cells treated with either agent alone. (C) The cell adhesion profile was analyzed by adhesion assays and western blot analysis of p-Pyk2 and p-FAK. Decreased cell adhesion ratios were observed for cells treated with 7RH and 7RH + dasatinib, as quantified using ImageJ software. Data are presented as the mean \pm standard deviation of triplicate experiments " $\mathrm{P}<0.05$ vs. control experiments within the same group. NPC, nasopharyngeal carcinoma; DDR1, discoidin domain receptor 1; SFK, SRC family kinase; p-, phosphorylated; ERK, extracellular signal-regulated kinase; 4EBP1, eukaryotic translation initiation factor 4E binding protein 1; MCL-1, myeloid cell leukemia-1; BCL-2, B-cell lymphoma-2; PARP, poly(ADP-ribose) polymerase 1; FAK, focal adhesion kinase; DMSO, dimethyl sulfoxide; FITC, fluorescein isothiocyanate. 
Table I. Dual inhibition of discoidin domain receptor 1 and SRC family kinase decreased the tumorigenicity of nasopharyngeal carcinoma cells in vitro.

\begin{tabular}{lccc}
\hline $7 \mathrm{RH}(\mu \mathrm{mol} / \mathrm{l})$ & Dasatinib $(\mu \mathrm{mol} / \mathrm{l})$ & $\mathrm{Fa}$ & $\mathrm{CI}$ \\
\hline 0.3125 & 1.25 & 0.377 & 0.289 \\
0.625 & 2.5 & 0.486 & 0.378 \\
1.25 & 5 & 0.738 & 0.268 \\
2.5 & 10 & 0.827 & 0.326 \\
5 & 20 & 0.840 & 0.596 \\
10 & 40 & 0.895 & 0.755 \\
\hline
\end{tabular}

CIs were determined using CalcuSyn software. A CI value $<1$ indicates a synergistic effect The results are representative of three independent experiments. CIs, combination indexes.

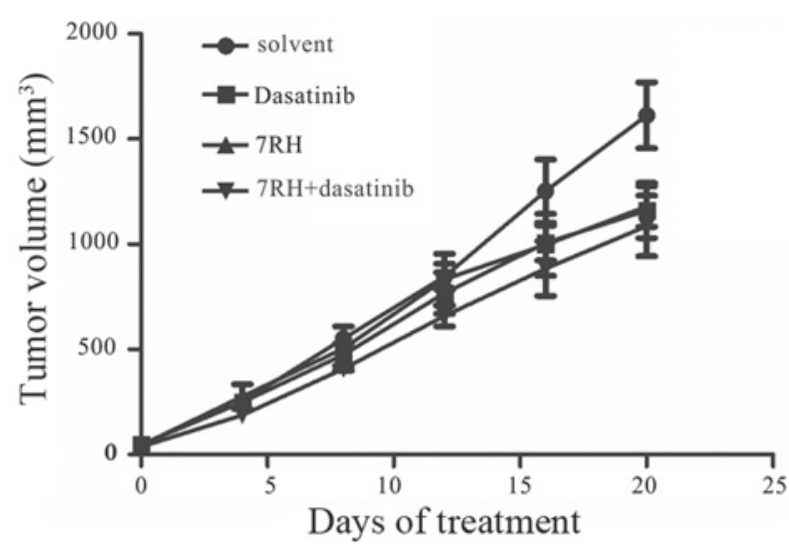

Figure 6. Dual inhibition of DDR1 and SFK decreased tumor growth of CNE2 cells in vivo. Nude mice were injected with CNE2 cells and divided into the following treatment groups: Normal saline, $7 \mathrm{RH}(8 \mathrm{mg} / \mathrm{kg} / \mathrm{day})$, dasatinib (10 mg/kg/day) and 7RH ( $8 \mathrm{mg} / \mathrm{kg} /$ day $) \pm$ dasatinib $(10 \mathrm{mg} / \mathrm{kg} / \mathrm{day})$. The effect of $7 \mathrm{RH}$ and dasatinib treatment alone or combination on tumor development was assessed by measuring tumor size every 4 days until the end of the treatment (day 20). Solvent vs. dasatinib, $\mathrm{P}=0.05$; solvent vs. $7 \mathrm{RH}$ $\mathrm{P}=0.04$; solvent vs. drug combination, $\mathrm{P}=0.03$. $\mathrm{P}$-values were calculated using the Student's t-test (two-sided). DDR1, discoidin domain receptor 1; SFK, SRC family kinase.

subsequently results in the dimerization of STAT proteins and their subsequent translocation into the nucleus where they interact with various regulatory gene expression elements, including c-Myc, CDK4, cyclin D1, p21 and the BCL-2 family (34). The present study demonstrated that the protein expression levels of c-Myc, CDK4, cyclin D1, P21 and BCL-2 family members in NPC cells were altered following treatment with $7 \mathrm{RH}$, indicating that $7 \mathrm{RH}$ affects the JAK/STAT3 signaling pathway.

The present study demonstrated that the PI3K/AKT signaling pathway and levels of $\mathrm{p}$-SRC tyrosine kinase in NPC cells were increased following 7RH treatment. Previous studies have reported that the SRC tyrosine kinase is overexpressed in variety of solid tumors, and is associated with the promotion of cell growth and proliferation via activation of the RAS/RAF/MEK/ERK and PI3K/AKT signaling pathways, as well as the promotion of metastasis by enhancing
FAK activity $(35,36)$. In the majority of human cancers, including NPC, the PI3K/AKT/mTOR signaling pathway is involved in cancer progression (26). It has been demonstrated that constitutively-activated AKT regulates cancer processes such as cell growth, cell cycle progression, invasion, migration, epithelial-mesenchymal transition and angiogenesis, as well as promoting resistance to chemotherapy and radiotherapy $(37,38)$. Similarly, SRC has been associated with cancer chemoresistance; SRC is involved in the development of resistance to trastuzumab, an anti-human epidermal growth factor receptor 2 (HER2) monoclonal antibody, used in breast cancer therapy (39). Consistent with this, activated forms of SRC and HER kinases are frequently identified in cancer, with HER kinases and SRC exhibiting hyperfunctionality in $\sim 70 \%$ of breast cancer cases (39). Furthermore, SRC is involved in the signal transduction mediated by HER kinases (40). In prostate cancer, SRC family kinases and FAK signaling are frequently hyperfunctional and have been associated with poor patient outcome, as well as resistance to antihormonal therapies (41). In addition, previous studies have demonstrated that SRC is involved in resistance to epidermal growth factor receptor inhibitors, which has been associated with poor outcomes in NPC patients treated with lapatinib and cetuximab $(42,43)$. The present study demonstrated that $7 \mathrm{RH}$ enhanced the activation of the PI3K/AKT signaling pathway, which was accompanied by increased protein expression levels of p-SRC. Similarly, knockdown of DDR1 by siRNA led to SRC activation. These results suggested that SRC exhibits a vital function in $7 \mathrm{RH}$ resistance by activating the PI3K/AKT signaling pathway.

Dasatinib is a small molecule tyrosine kinase inhibitor, initially isolated as a dual SRC/Abelson murine leukemia viral oncogene homolog 1 inhibitor (44). Dasatinib inhibits SFKs, including LCK, HCK, FYN, YES, FGR, BLK, LYN, and FRK (45). Furthermore, dasatinib blocks the kinase activities of certain RTKs with high potency, including c-KIT, c-FMS, platelet-derived growth factor receptors A and B, DDR1 and Ephrin receptors (46). Several preclinical studies have demonstrated that dasatinib potentiates the antitumor effects of various drugs used clinically: Trials using combinations of dasatinib with ErbB/HER antagonists have been performed for breast (47), head and neck (48) and colorectal cancer (49). The present study demonstrated that dasatinib used in combination with agents targeting DDR1 presents a potential therapeutic strategy for NPC.

Notably, in the present study, combined treatment of NPC cells with dasatinib and 7RH decreased the expression levels of p-AKT when compared with either drug treatment alone. It has been demonstrated that AKT exerts its cellular effects via the phosphorylation of $>20$ substrate proteins, including members of the forkhead protein family (FKHR, FKHRL1 and AFX), mTOR, MDM2 and Bad (50). In the present study, the phosphorylation levels of downstream targets of mTORC1, such as 4EBP-1, were decreased following the combined drug treatment when compared with single treatments. In addition, the MAPK signaling pathway was altered in response to combined dasatinib and $7 \mathrm{RH}$ treatment. The inhibition of multiple signaling pathways indicated that the synergistic antitumor effects of the combined drug treatment may have resulted from the inhibition of multiple signaling pathways involved in the control of cell proliferation and survival. 
In the present study, 7RH and dasatinib exhibited antitumor effects in vivo. These results suggested that DDR1 may be considered a potential molecular target for NPC treatment.

In conclusion, the present study demonstrated that the DDR1 inhibitor 7RH was able to suppress NPC cells in vitro, via the inhibition of JAK1/STAT3 signaling pathway activation. SRC was demonstrated to exhibit a vital function in the resistance of NPC cells to 7RH via activation of the PI3K/AKT signaling pathway. Notably, the present study formed a conceptual basis for the application of combination chemotherapy targeting both DDR1 and SFK for the treatment of patients with NPC in the future.

\section{Acknowledgements}

The present study was supported by the National Natural Science Foundation of China (grant no. 30873009). The authors would like to thank Dr Ding Ke for providing 7RH.

\section{References}

1. Chin D, Boyle GM, Porceddu S, Theile DR, Parsons PG and Coman WB: Head and neck cancer: Past, present and future. Expert Rev Anticancer Ther 6: 1111-1118, 2006.

2. Tao Q and Chan AT: Nasopharyngeal carcinoma: Molecular pathogenesis and therapeutic developments. Expert Rev Mol Med 9: 1-24, 2007.

3. Lo KW, To KF and Huang DP: Focus on nasopharyngeal carcinoma. Cancer Cell 5: 423-428, 2004.

4. Robinson DR, Wu YM and Lin SF: The protein tyrosine kinase family of the human genome. Oncogene 19: 5548-5557, 2000.

5. Valiathan RR, Marco M, Leitinger B, Kleer CG and Fridman R: Discoidin domain receptor tyrosine kinases: New players in cancer progression. Cancer Metastasis Rev 31: 295-321, 2012.

6. Hidalgo-Carcedo C, Hooper S, Chaudhry SI, Williamson P, Harrington K, Leitinger B and Sahai E: Collective cell migration requires suppression of actomyosin at cell-cell contacts mediated by DDR 1 and the cell polarity regulators Par3 and Par6. Nat Cell Biol 13: 49-58, 2011.

7. Chua HH, Yeh TH, Wang YP, Huang YT, Sheen TS, Lo YC, Chou YC and Tsai $\mathrm{CH}$ : Upregulation of discoidin domain receptor 2 in nasopharyngeal carcinoma. Head Neck 30: 427-436, 2008.

8. Laval S, Butler R, Shelling AN, Hanby AM, Poulsom R and Ganesan TS: Isolation and characterization of an epithelial-specific receptor tyrosine kinase from an ovarian cancer cell line. Cell Growth Differ 5: 1173-1183, 1994.

9. Shen Q, Cicinnati VR, Zhang X, Iacob S, Weber F, Sotiropoulos GC, Radtke A, Lu M, Paul A, Gerken G and Beckebaum S: Role of microRNA-199a-5p and discoidin domain receptor 1 in human hepatocellular carcinoma invasion. Mol Cancer 9: 227, 2010

10. Ford CE, Lau SK, Zhu CQ, Andersson T, Tsao MS and Vogel WF: Expression and mutation analysis of the discoidin domain receptors 1 and 2 in non-small cell lung carcinoma. Br J Cancer 96: 808-814, 2007.

11. Barker KT, Martindale JE, Mitchell PJ, Kamalati T, Page MJ, Phippard DJ, Dale TC, Gusterson BA and Crompton MR: Expression patterns of the novel receptor-like tyrosine kinase, DDR, in human breast tumours. Oncogene 10: 569-575, 1995.

12. Weiner HL, Rothman M, Miller DC and Ziff EB: Pediatric brain tumors express multiple receptor tyrosine kinases including novel cell adhesion kinases. Pediatr Neurosurg 25: 64-72, 1996.

13. Nemoto T, Ohashi K, Akashi T, Johnson JD and Hirokawa K: Overexpression of protein tyrosine kinases in human esophageal cancer. Pathobiology 65: 195-203, 1997.

14. Squire JA, Bayani J, Luk C, Unwin L, Tokunaga J, MacMillan C, Irish J, Brown D, Gullane P and Kamel-Reid $\mathrm{S}$ : Molecular cytogenetic analysis of head and neck squamous cell carcinoma: By comparative genomic hybridization, spectral karyotyping, and expression array analysis. Head Neck 24: 874-887, 2002.
15. Shimada K, Nakamura M, Ishida E, Higuchi T, Yamamoto $\mathrm{H}$, Tsujikawa $\mathrm{K}$ and Konishi N: Prostate cancer antigen-1 contributes to cell survival and invasion though discoidin receptor 1 in human prostate cancer. Cancer Sci 99: 39-45, 2008.

16. Rodrigues R, Roque L, Espadinha C, Pinto A, Domingues R, Dinis J, Catarino A, Pereira T and Leite V: Comparative genomic hybridization, BRAF, RAS, RET, and oligo-array analysis in aneuploid papillary thyroid carcinomas. Oncol Rep 18: 917-926, 2007.

17. Hajdu M, Singer S, Maki RG, Schwartz GK., Keohan ML and Antonescu CR: IGF2 over-expression in solitary fibrous tumours is independent of anatomical location and is related to loss of imprinting. J Pathol 221: 300-307, 2010.

18. Chiaretti S, Li X, Gentleman R, Vitale A, Wang KS, Mandelli F, Foà R and Ritz J: Gene expression profiles of B-lineage adult acute lymphocytic leukemia reveal genetic patterns that identify lineage derivation and distinct mechanisms of transformation. Clin Cancer Res 11: 7209-7219, 2005.

19. Abdulhussein R, Koo DH and Vogel WF: Identification of disulfide-linked dimers of the receptor tyrosine kinase DDR1. J Biol Chem 283: 12026-12033, 2008.

20. Konitsiotis AD, Raynal N, Bihan D, Hohenester E, Farndale RW and Leitinger B: Characterization of high affinity binding motifs for the discoidin domain receptor DDR2 in collagen. J Biol Chem 283: 6861-6868, 2008.

21. Hou G, Vogel WF and Bendeck MP: Tyrosine kinase activity of discoidin domain receptor 1 is necessary for smooth muscle cell migration and matrix metalloproteinase expression. Circ Res 90: 1147-1149, 2002.

22. Agarwal G, Mihai C and Iscru DF: Interaction of discoidin domain receptor 1 with collagen type 1 . J Mol Biol 367: 443-455, 2007.

23. Vogel WF, Abdulhussein R and Ford CE: Sensing extracellular matrix: An update on discoidin domain receptor function. Cell Signal 18: 1108-1116, 2006.

24. Valencia K, Ormazábal C, Zandueta C, Luis-Ravelo D, Antón I, Pajares MJ, Agorreta J, Montuenga LM, Martínez-Canarias S, Leitinger B and Lecanda F: Inhibition of collagen receptor discoidin domain receptor-1 (DDR1) reduces cell survival, homing, and colonization in lung cancer bone metastasis. Clin Cancer Res 18: 969-980, 2012.

25. Koon HK, Chan PS, Wong RN, Wu ZG, Lung ML, Chang CK and Mak NK: Targeted inhibition of the EGFR pathways enhances Zn-BC-AM PDT-induced apoptosis in well-differentiated nasopharyngeal carcinoma cells. J Cell Biochem 108: 1356-1363, 2009.

26. Ligresti G, Militello L, Steelman LS, Cavallaro A, Basile F, Nicoletti F, Stivala F, McCubrey JA and Libra M: PIK3CA mutations in human solid tumors: Role in sensitivity to various therapeutic approaches. Cell Cycle 8: 1352-1358, 2009.

27. Summy JM and Gallick GE: Src family kinases in tumor progression and metastasis. Cancer Metastasis Rev 22: 337-358, 2003.

28. Gao M, Duan L, Luo J, Zhang L, Lu X, Zhang Y, Zhang Z, Tu Z, Xu Y, Ren X and Ding K: Discovery and optimization of 3-(2-(Pyrazolo[1,5-a]pyrimidin-6-yl)ethynyl) benzamides as novel selective and orally bioavailable discoidin domain receptor 1 (DDR1) inhibitors. J Med Chem 56: 3281-3295, 2013.

29. Care NRCU, Animals AUOL. Guide for the Care and Use of Laboratory Animals. National Academies Press (US), Washington DC, 2011.

30. Eswaramoorthy R, Wang CK, Chen WC, Tang MJ, Ho ML, Hwang CC, Wang HM and Wang CZ: DDR1 regulates the stabilization of cell surface E-cadherin and E-cadherin- mediated cell aggregation. J Cell Physiol 224: 387-397, 2010.

31. Yeh YC, Wu CC, Wang YK and Tang MJ: DDR1 triggers epithelial cell differentiation by promoting cell adhesion through stabilization of E-cadherin. Mol Biol Cell 22: 940-953, 2011.

32. Ongusaha PP, Kim JI, Fang L, Wong TW, Yancopoulos GD, Aaronson SA and Lee SW: p53 induction and activation of DDR1 kinase counteract p53-mediated apoptosis and influence p53 regulation through a positive feedback loop. EMBO J 22: 1289-1301, 2003.

33. Kim HG, Hwang SY, Aaronson SA, Mandinova A and Lee SW: DDR1 receptor tyrosine kinase promotes prosurvival pathway through Notch1 activation. J Biol Chem 286: 17672-17681, 2011.

34. Vainchenker $\mathrm{W}$ and Constantinescu SN: JAK/STAT signaling in hematological malignancies. Oncogene 32: 2601-2613, 2013. 
35. Konig H, Copland M, Chu S, Jove R, Holyoake TL and Bhatia R: Effects of dasatinib on SRC kinase activity and downstream intracellular signaling in primitive chronic myelogenous leukemia hematopoietic cells. Cancer Res 68: 9624-9633, 2008.

36. Thamilselvan V, Craig DH and Basson MD: FAK association with multiple signal proteins mediates pressure-induced colon cancer cell adhesion via a Src-dependent PI3K/Akt pathway. FASEB J 21: 1730-1741, 2007.

37. Chin YR and Toker A: Function of Akt/PKB signaling to cell motility, invasion and the tumor stroma in cancer. Cell Signal 21: 470-476, 2009

38. LoPiccolo J, Blumenthal GM, Bernstein WB and Dennis PA: Targeting the PI3K/Akt/mTOR pathway: Effective combinations and clinical considerations. Drug Resist Updat 11: 32-50, 2008.

39. Zhang S, Huang WC, Li P, Guo H, Poh SB, Brady SW, Xiong Y, Tseng LM, Li SH, Ding Z, et al: Combating trastuzumab resistance by targeting SRC, a common node downstream of multiple resistance pathways. Nat Med 17: 461-469, 2011

40. Ishizawar RC, Miyake T and Parsons SJ: c-Src modulates ErbB2 and ErbB3 heterocomplex formation and function. Oncogene 26: 3503-3510, 2007.

41. Tatarov O, Mitchell TJ, Seywright M, Leung HY, Brunton VG and Edwards J: SRC family kinase activity is up-regulated in hormone-refractory prostate cancer. Clin Cancer Res 15: 3540-3549, 2009.

42. Lui VW, Lau CP, Ho K, Ng MH, Cheng SH, Tsao SW, Tsang CM, Lei KI, Chan AT and Mok TS: Anti-invasion, anti-proliferation and anoikis-sensitization activities of lapatinib in nasopharyngeal carcinoma cells. Invest New Drugs 29: 1241-1252, 2011.

43. Sung FL, Pang RT, Ma BB, Lee MM, Chow SM, Poon TC and Chan AT: Pharmacoproteomics study of cetuximab in nasopharyngeal carcinoma. J Proteome Res 5: 3260-3267, 2006.
44. Lombardo LJ, Lee FY, Chen P, Norris D, Barrish JC, Behnia K, Castaneda S, Cornelius LA, Das J, Doweyko AM, et al: Discovery of N-(2-chloro-6-methyl- phenyl)-2-(6-(4-(2-hydroxyethyl)-p iperazin-1-yl)-2-methylpyrimidin-4-ylamino)thiazole-5-carboxamide (BMS-354825), a dual Src/Abl kinase inhibitor with potent antitumor activity in preclinical assays. J Med Chem 47: 6658-6661, 2004.

45. Karaman MW, Herrgard S, Treiber DK, Gallant P, Atteridge CE, Campbell BT, Chan KW, Ciceri P, Davis MI, Edeen PT, et al: A quantitative analysis of kinase inhibitor selectivity. Nat Biotechnol 26: 127-132, 2008.

46. Rix U, Hantschel O, Dürnberger G, Remsing Rix LL, Planyavsky M, Fernbach NV, Kaupe I, Bennett KL, Valent P, Colinge J, et al: Chemical proteomic profiles of the BCR-ABL inhibitors imatinib, nilotinib, and dasatinib reveal novel kinase and nonkinase targets. Blood 110: 4055-4063, 2007.

47. Seoane S, Montero JC, Ocaña A and Pandiella A: Effect of multikinase inhibitors on caspase-independent cell death and DNA damage in HER2-overexpressing breast cancer cells. J Natl Cancer Inst 102: 1432-1446, 2010.

48. Johnson FM, Saigal B, Talpaz M and Donato NJ: Dasatinib (BMS-354825) tyrosine kinase inhibitor suppresses invasion and induces cell cycle arrest and apoptosis of head and neck squamous cell carcinoma and non-small cell lung cancer cells. Clin Cancer Res 11: 6924-6932, 2005.

49. Koppikar P, Choi SH, Egloff AM, Cai Q, Suzuki S, Freilino M, Nozawa H, Thomas SM, Gooding WE, Siegfried JM and Grandis JR: Combined inhibition of c-Src and epidermal growth factor receptor abrogates growth and invasion of head and neck squamous cell carcinoma. Clin Cancer Res 14: 4284-4291, 2008.

50. Hers I, Vincent EE and Tavaré JM: Akt signalling in health and disease. Cell Signal 23: 1515-1527, 2011. 